\title{
Genetic association studies of the FOXP3 gene in Graves' disease and autoimmune Addison's disease in the United Kingdom population
}

\author{
Catherine J Owen ${ }^{1,2}$, James A Eden ${ }^{1}$, Claire E Jennings ${ }^{1}$, Valerie Wilson ${ }^{1}$, \\ Tim D Cheetham ${ }^{2}$ and Simon H S Pearce ${ }^{1}$
}

${ }^{1}$ Institute of Human Genetics, International Centre for Life, ${ }^{2}$ Department of Child Health, School of Clinical and Medical Sciences, University of Newcastle, Central Parkway, Newcastle
upon Tyne NE1 3BZ, UK

(Requests for offprints should be addressed to C J Owen; Email: c.j.owen@ncl.ac.uk)

\begin{abstract}
Regulatory T lymphocytes play a crucial role in modulating potentially self-reactive clones, and dysfunction of this cell type contributes to autoimmune disease. FOXP3 is a critical determinant of $C D^{4+} C D^{25+} T$ regulatory $\left(T_{\text {reg }}\right)$ cell development and function. The aim of this study was to investigate whether genetic polymorphisms at the FOXP3 locus predispose to autoimmune endocrinopathies. Five single nucleotide polymorphisms (SNPs) and two microsatellite polymorphisms were genotyped in our Caucasian cohorts of 633 unrelated Graves' disease (GD) subjects, 104 autoimmune Addison's disease (AAD) subjects and 528 healthy controls. SNP genotyping was performed by either restriction enzyme digestion or by primer-extension-MALDI-TOF (matrix-assisted laser desorption/ionisation time-offlight) assay. Microsatellites were analysed using fluorescent PCR. Case-control analysis was performed using $\chi^{2}$ testing on contingency tables for allele frequency. Haplotype analysis was performed using the UNPHASED package. No evidence for disease association was found with any of the seven polymorphisms in either of the GD or AAD subjects as compared with controls $(P=0 \cdot 26-0 \cdot 94)$. Haplotype analysis found a weak evidence for the association of a minor haplotype with GD; this was not significant when corrected for multiple testing. This study has found no robust evidence that FOXP3 gene polymorphism contributes to the susceptibility to GD or AAD in the UK population.
\end{abstract}

Journal of Molecular Endocrinology (2006) 37, 97-104

\section{Introduction}

Autoimmune endocrinopathies, including Graves' disease (GD) and autoimmune Addison's disease $(\mathrm{AAD})$, are the commonest type of autoimmunity in Western populations. However, their pathogenesis remains poorly defined. Like many other autoimmune disorders, they are thought to result from a failure of the normal immune tolerance mechanisms, which includes pathogenic $\mathrm{T}$ cells directed against selfantigens. $\mathrm{CD}^{4+} \mathrm{CD}^{25+} \mathrm{T}$ regulatory cells $\left(\mathrm{T}_{\text {reg }}\right)$ have a role in the modulation of potentially self-reactive T-cell clones, as they actively suppress the immune responses of autoreactive T cells (Maloy \& Powrie 2001, Sakaguchi et al. 2001). A lack of regulatory T cells in mice caused by mutation of the FOXP3 gene leads to severe organspecific autoimmunity (Brunkow et al. 2001). Recessive $\mathrm{X}$-linked mutations in the FOXP3 gene have also been found to be responsible for the immunodysregulation, polyendocrinopathy and enteropathy, X-linked syndrome (IPEX) in humans (Chatila et al. 2000, Bennett et al. 2001b, Wildin et al. 2001). This is a rare and devastating lymphoproliferative condition of male infants resulting in multiple autoimmune disorders, in particular enteropathy, diabetes mellitus, haemolytic anaemia and thyroid autoimmunity (Wildin et al. 2002). Several mutations distributed throughout the FOXP3 gene have been shown to be responsible for many cases of IPEX (Bennett et al. 2001a, Kobayashi et al. 2001, Wildin et al. 2002, Gambineri et al. 2003, Owen et al. 2003). Rare monogenic phenotypes like this can be helpful in identifying genes, which may also contribute to the commoner complex genetic conditions. FOXP3 is a forkhead/winged helix transcription factor, which has been shown to be specifically expressed in naturally arising regulatory $\mathrm{T}$ cells, and can convert naïve $\mathrm{T}$ cells to this regulatory phenotype (Fontenot et al. 2003, Hori et al. 2003, Khattri et al. 2003, Walker et al. 2003a). Thus, FOXP3 is a critical regulator of regulatory T-cell development and function. It has been shown that expression of FOXP3 in $\mathrm{CD}^{4+} \mathrm{T}$ cells correlates with their ability to function as regulatory $\mathrm{T}$ cells (Walker et al. 2003b).

Although IPEX represents an extreme autoimmune phenotype, reduced circulating numbers of regulatory T cells have been reported in the commoner conditions such as type 1 diabetes (T1D), multiple sclerosis and autoimmune polyglandular syndrome type II (Kukreja

DOI: $10.1677 /$ jme.1.02072 Online version via http://www.endocrinology-journals.org 
et al. 2002, Kriegel et al. 2004, Huan et al. 2005). One of these studies showed that the impaired regulatory T-cell function was linked to abnormalities in FOXP3 message and protein expression levels within the cells (Huan et al. 2005). Thus, structural, quantitative or regulatory polymorphism at the FOXP3 locus may be contributing to the susceptibility of these commoner conditions. Thus, FOXP3 is a good candidate gene to play a role in organ-specific autoimmune diseases, in particular diabetes mellitus and thyroid autoimmunity, in view of their prominence in the IPEX syndrome.

As with many other autoimmune disorders, there is a marked gender bias in both GD and AAD prevalence, with a female to male ratio of at least 5:1 in GD (Tunbridge et al. 1977) and 3:1 in AAD (Laureti et al. 1999). However, the reason for this is unclear. One explanation could be related to genes residing on the sex chromosomes, which in the setting of a complex inheritance pattern may alter the risk for the development of autoimmunity (Barbesino et al. 1998, Lockshin 2002). Recently, skewed X-inactivation has been demonstrated in autoimmune thyroid disease and other forms of autoimmunity (Ozbalkan et al. 2005, Ozcelik et al. 2006). Furthermore, it has been hypothesised that skewed X-inactivation in the thymus may lead to inadequate thymic deletion of certain X-linked self-antigens (Stewart 1998, Chitnis et al. 2000). Two genome-wide scans for linkage in GD have identified putative X-chromosome loci, Xq21 (Tomer et al. 1999) and Xp11 (Taylor et al. 2006), and these loci have also been identified in localised linkage scans of the X-chromosome, Xq21 (Barbesino et al. 1998) and Xp11 (Imrie et al. 2001). However, several other genome-wide linkage scans in GD in a variety of different populations have found no evidence of linkage to the X-chromosome (Sakai et al. 2001, Allen et al. 2003, Jin et al. 2003, Tomer et al. 2003). Xp11 has also been linked to other autoimmune disorders: T1D, multiple sclerosis and rheumatoid arthritis, suggesting the presence of common susceptibility polymorphism(s) (Ebers et al. 1996, Cornelis et al. 1998, Cucca et al. 1998). The FOXP3 gene is located at Xp11.23 within this area of autoimmune disease linkage, thus strengthening its position as a putative susceptibility gene in autoimmune disease, particularly disorders showing a female predominance.

Bassuny and colleagues (2003) reported an association of a functional microsatellite polymorphism, (GT) $n$, located in the promoter/enhancer region of FOXP3, with T1D in a Japanese population. Subsequently, a detailed and comprehensive haplotype survey of five FOXP3 polymorphisms including the (GT) $n$ promoter microsatellite was carried out in a large T1D cohort (Zavattari et al. 2004). However, this study did not replicate the previous findings, showing no evidence of an association between FOXP3 and T1D
(Zavattari et al. 2004). The role of FOXP3 in other autoimmune diseases, particularly inflammatory bowel disease, has also recently been investigated, again with discrepant results (Park et al. 2005, Sanchez et al. 2005).

We hypothesise that FOXP3 may be a stronger candidate gene for the autoimmune disorders, which in contrast to T1D, exhibit a marked female predominance. Therefore, the aim of this study was to examine whether polymorphisms in the FOXP3 gene may contribute to the susceptibility to GD and AAD in our United Kingdom (UK) cohort of unrelated patients.

\section{Materials and methods}

\section{Subjects}

Blood samples were obtained from 633 GD probands, of which $495(78.2 \%)$ were female, and $104 \mathrm{AAD}$ probands, of which $73(70 \cdot 2 \%)$ were female. Patients were all of Caucasian origin from the northeast of England, and were recruited through endocrine and thyroid eye clinics at the Newcastle upon Tyne Hospitals Trust and surrounding district hospitals. GD was defined by the biochemical presence of hyperthyroidism together with one of either a diffuse increase in thyroid uptake on ${ }^{99-}$ Tc radionucleotide scanning, positive thyroid autoantibodies (thyroid peroxidase (TPO) or thyroid binding inhibiting immunoglobulin (TBII)) or thyroid-associated opthalmopathy (NOSPECS class 3 or worse) (Werner 1977). All AAD probands had biochemical evidence of adrenal failure and infective and infiltrative causes were excluded, as were patients with Acebutolol et Prevention Secondaire de l'Infarctus (APS1).

Totally 528 controls, of which $350(66 \cdot 3 \%)$ were female, were recruited from the same local population to determine background population allele frequencies. All were Caucasian and had parents born in the northeast of England. They had no clinical features or family history of autoimmune disease.

All the studies were approved by the Newcastle and North Tyneside ethics committee and all subjects gave informed consent.

\section{Selection of polymorphisms in the FOXP3 gene}

Seven polymorphisms (five single nucleotide polymorphisms (SNPs) and two microsatellites) were selected for genotyping in our patient and control cohorts (Fig. 1). These spanned $15 \cdot 7 \mathrm{~kb}$ of the FOXP3 region, with three being promoter SNPs, two intronic and two located in the $3^{\prime}$ UTR. The SNPs were selected to extract the most genetic information based on marker frequency (minor allele frequency $(\mathrm{MAF})>5 \%$ ) and haplotype data using the HAPMAP database (http:// www.hapmap.org) (Altshuler et al. 2005) and the 


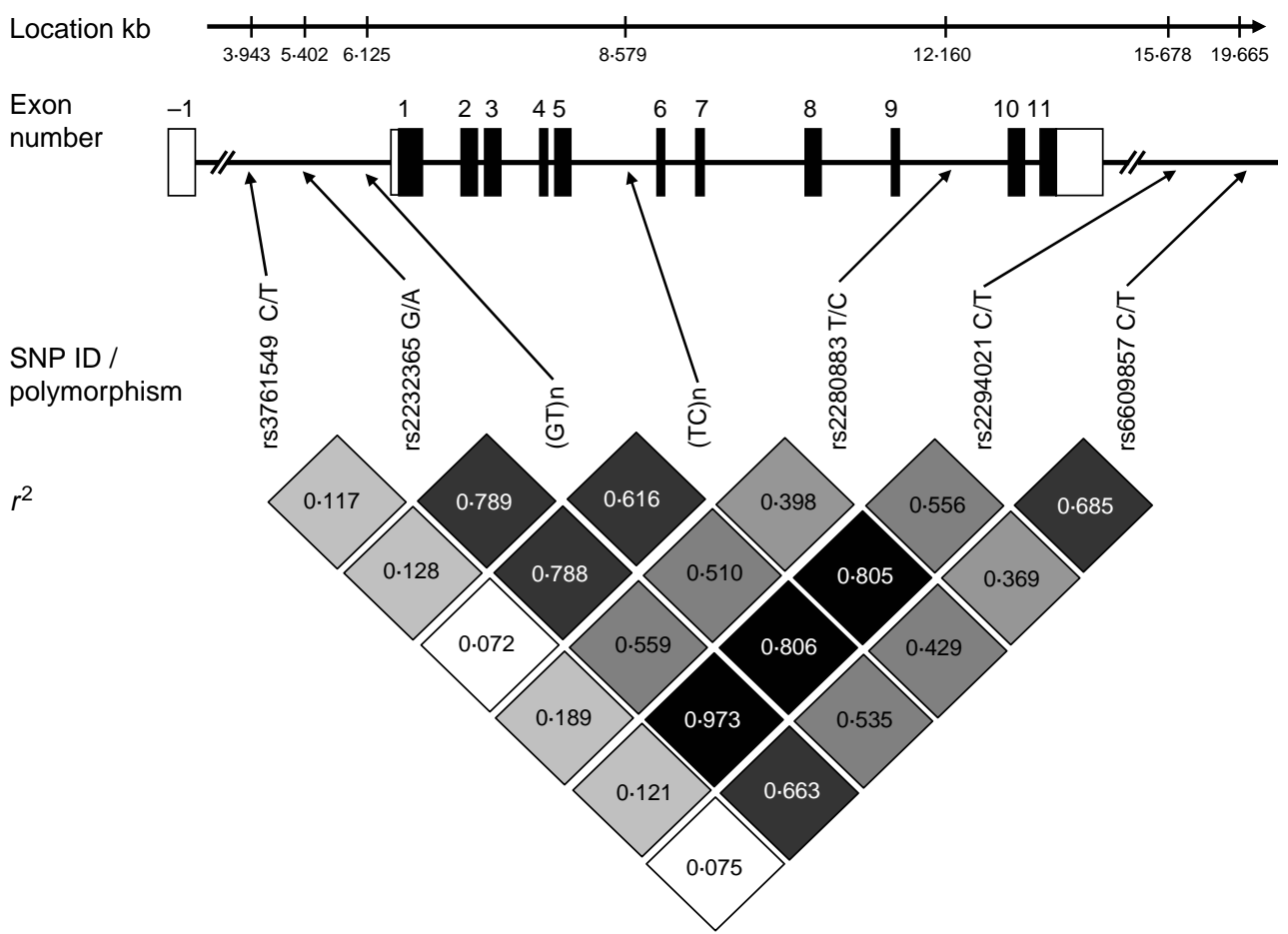

Figure 1 Schematic structure of the 12 exons (one of which, -1 , is non-coding) of the FOXP3 gene. Exons are depicted by black boxes and non-coding regions as white boxes. The position of the five SNPS and two microsatellites spanning $15.7 \mathrm{~kb}$ of the FOXP3 region are shown by the arrows. The SNP ID, polymorphism, position in relation to the transcription start site $(\mathrm{kb})$ and the pairwise linkage disequilibrium $\left(r^{2}\right)$ measures between the seven polymorphisms are detailed below. The white boxes represent the lowest $r^{2}$ values, while darker the shading the higher the $r^{2}$ value between the relevant markers.

HAPLOVIEW program (Barrett $e t$ al. 2005). No exonic SNPs were included as there are no informative exonic SNPs reported in the HAPMAP and other SNP databases. The five SNPs selected covered the common SNP haplotype blocks in the FOXP3 gene, i.e. the haplotype 'tag' SNPs, rs3761549, rs2280883, rs2294021 and rs6609857. One further SNP from the Zavattari et al. (2004) study was also included, rs2232365. This study identified a set of SNPs, which extracted the most genetic information from the FOXP3 gene and the rs2232365 SNP was the only one of these SNPs that was not included in the HAPMAP analysis of the FOXP3 gene. The two microsatellites typed by Bassuny and colleagues (2003) were also genotyped, in view of their finding of the association of these microsatellites with T1D.

\section{Single nucleotide polymorphism genotyping}

Genomic DNA was extracted from peripheral blood leukocytes using the Nucleon BACC2 kit (Amersham Pharmacia Biotech). Genotyping was performed by PCR and restriction enzyme digest (RFLP) for one of the SNPs (rs3761549) and by primer-extension-
MALDI-TOF assay (Sequenom, San Diego, CA, USA) for the other four SNPs. Details of the primers and reaction conditions are given in Table 1 .

\section{Genotyping of (GT)n and (TC)n microsatellite polymorphisms}

PCR primer pairs, sequences and nomenclature as described previously (Bassuny et al. 2003) were used to amplify intron zero containing the (GT) $n$ microsatellite polymorphism (located in IVS0 from -150 to -177 , up to -187 ) and intron five containing the (TC) $n$ microsatellite polymorphism (located in IVS5 from +476 to +595 , up to +539 ). The $5^{\prime}$ end of each of the forward primers was labelled with a fluorescent dye, 6-carboxyfluorescein (FAM) dye for the (GT) $n$ forward primer, and 6-carboxy-2',4,7,7'-tetrachlorofluorescein (TET) dye for the (TC) $n$ forward primer. Genotyping was performed in a mixture of both (GT) $n$ and (TC) $n$ amplified products, together with a 400 bp size standard (Amersham Rox ET400) by the MegaBACE sequencing instrument (Amersham Pharmacia Biotech). Results were analysed using the MegaBACE genetic profiler software (Amersham). In 
Table 1 Details of the primers and enzymes used for the PCR/RFLP genotyping assay, and the primers and termination mix for the SNPs genotyped by MALDI-TOF mass spectrometry (Sequenom). Multiplex assays were designed using the MassARRAY assay design software program (Sequenom)

\begin{tabular}{|c|c|c|c|c|}
\hline \multirow[b]{2}{*}{ dbSNP ID } & Nucleotide change & \multirow[t]{2}{*}{ Forward primer } & \multirow[t]{2}{*}{ Reverse primer } & \multirow[t]{2}{*}{ Restriction enzym } \\
\hline & & & & \\
\hline \multicolumn{5}{|c|}{ RFLP/PCR genotyping } \\
\hline rs3761549 & $\mathrm{C} / \mathrm{T}$ & $\begin{array}{l}\text { CTGAGACTTTGGGACCG- } \\
\text { TAG }\end{array}$ & $\begin{array}{l}\text { TGCGCCGGGCTTCATC- } \\
\text { GACA }\end{array}$ & BseN1 \\
\hline \multicolumn{5}{|c|}{ SEQUENOM genotyping } \\
\hline & $\begin{array}{l}\text { Primer } 1 \\
\text { ACGTTGGATGAGGCTT- } \\
\text { GAGGGCCAGAAATT }\end{array}$ & $\begin{array}{l}\text { Primer } 2 \\
\text { ACGTTGGATGTGG- } \\
\text { CAAGTGACAGAGAGGAG }\end{array}$ & $\begin{array}{l}\text { Extension primer } \\
\text { GCCCCAGCTCAAGA- } \\
\text { GACCCC }\end{array}$ & $\begin{array}{l}\text { Termination mix } \\
\text { ACT }\end{array}$ \\
\hline rs2280883 & $\begin{array}{l}\text { GTTGGATGAGCCTT- } \\
\text { TATGCCAACCCAA }\end{array}$ & $\begin{array}{l}\text { ACGTTGGAT- } \\
\text { GATGGGTGTTACAAG- } \\
\text { GAAAGG }\end{array}$ & ACCCCCAACTGGGCACC & ACT \\
\hline rs2294021 & $\begin{array}{l}\text { ACGTTGGATGAGACAA- } \\
\text { GATCTGGCAGACAC }\end{array}$ & $\begin{array}{l}\text { ACGTTGGATGTACACAT- } \\
\text { GAGGACCCTCCAC }\end{array}$ & $\begin{array}{l}\text { AGATCTGGCAGACAC- } \\
\text { CATGGC }\end{array}$ & ACT \\
\hline rs6609857 & $\begin{array}{l}\text { ACGTTGGATGATACA- } \\
\text { GAGGTGGACAGAGAG }\end{array}$ & $\begin{array}{l}\text { ACGTTGGATGTGTGTT- } \\
\text { CACCCAGGTATCAG }\end{array}$ & AGGAAGAGGGGACAGAT & ACT \\
\hline
\end{tabular}

order to confirm the repeat number of polymorphisms for PCR product length, alleles from six males of each of the two commonest genotypes for each polymorphism (24 alleles in total) were subject to direct DNA sequencing using the MegaBACE sequencing instrument.

\section{Statistical analysis}

The case-control association studies were analysed using $\chi^{2}$ tests on $2 \times 2,2 \times 6$ or $2 \times 20$ contingency tables for allele frequencies depending upon allele number. Haplotype frequencies were estimated using the UNPHASED package (Dudbridge 2003). Odds ratios and confidence intervals were calculated using Woolf's method (Woolf 1995). Observed and expected genotypes in female samples were compared using the Hardy-Weinberg equation. This study had $80 \%$ power to detect an effect with an odds ratio of $1 \cdot 25$ for the most informative SNP rs2280883 ( $\alpha=0 \cdot 05)$, and $>90 \%$ power to detect an effect with an odds ratio of 1.5 for all the SNPs $(\alpha=0.05)$, given the actual control allele frequencies found.

\section{Results}

The seven polymorphisms were genotyped in a total of 1128 GD chromosomes, 177 AAD chromosomes and 878 control chromosomes. The allele frequency data, together with odds ratios are shown in Table 2 . In a marker-by-marker analysis using $\chi^{2}$ testing, there was no significant difference in allele frequency and thus no evidence for disease association with any of the seven polymorphisms in either GD or AAD probands as compared to controls was found (Table 2). Analysis of each polymorphism in the subset of 244 GD subjects with thyroid-associated opthalmopathy vs controls also showed no significant difference in allele frequency (data not shown). Haplotype analysis was carried out on the five SNP haplotypes as shown in Table 3. One of these haplotypes 'CATTC', showed weak association in the GD patients with a $\chi^{2}$ of $6 \cdot 05$, uncorrected $P=0 \cdot 01$ and an odds ratio of $1 \cdot 51(1 \cdot 09-$ $2 \cdot 11,95 \%$ confidence interval (C.I.)). However, this difference did not reach a statistical significance after a Bonferroni multiple adjustment for the 15 possible haplotypes was seen.

Haplotype analysis of all seven markers was also carried out. Five common haplotypes (frequency $>0.01$ in all the three groups) were identified. Taking into account the number of haplotype permutations seen $(n>20)$, none of these showed an association after correcting for multiple testing.

\section{Discussion}

This study has found no robust evidence for the FOXP3 gene contributing to the susceptibility to GD or AAD in our northeast England population. This is in contrast to the original study by Bassuny et al. (2003), who found a significantly higher frequency of the $(\mathrm{GT})_{15}$ allele of the microsatellite (GT) $n$ marker in Japanese patients with T1D compared with controls. They went on to demonstrate a significant difference in the enhancer activity of the $(\mathrm{GT})_{15}$ compared with the $(\mathrm{GT})_{16}$ allele in a dual-luciferase reporter assay. Zavattari et al. (2004) were unable to replicate this association when they examined five polymorphisms in a Sardinian T1D population, and thus concluded that 
Table 2 Allele frequencies for the seven FOXP3 polymorphisms in controls, GD and AAD together with case-control analysis of the alleles in each disease group in comparison with controls

Control chromosomes $n(\%)$ GD chromosomes $n(\%)$

Odds ratio (95\% C.I.)

$P$ value

AAD chromosomes Odds ratio $n(\%)$ (95\% C.I.)

$P$ value

\section{Marker}

rs3761549

C $\quad 682(85 \cdot 7)$

$\mathrm{T} \quad 114(14 \cdot 3)$

Total 796

rs2232365

$\begin{array}{ll}\text { G } & 489(62.5) \\ \text { A } & 293(37.5)\end{array}$

Total 782

(GT)n

$\begin{array}{lr}3 & 492(56 \cdot 1) \\ 4 & 333(38 \cdot 0) \\ 5 & 46(5 \cdot 3) \\ \text { Other } & 5(0 \cdot 6) \\ \text { Total } & 876\end{array}$

(TC) $n$

4

12

14

Other

Total

rs2280883

T $418(53.6)$

C $\quad 362(46 \cdot 4)$

Total $\quad 780$

rs2294021

C $\quad 484(62 \cdot 3)$

$\mathrm{T} \quad 293(37 \cdot 7)$

Total $\quad 777$

rs6609857

C $\quad 566(72.9)$

Total

$977(87 \cdot 3)$
$142(12 \cdot 7)$
1119

$675(60 \cdot 9)$
$433(39 \cdot 1)$
1108
$516(52 \cdot 9)$
$396(40 \cdot 6)$
$59(6 \cdot 1)$
$4(0 \cdot 4)$
975

$565(57 \cdot 7)$
$87(8 \cdot 9)$
$145(14 \cdot 8)$
$182(18 \cdot 6)$
979

$591(53 \cdot 4)$
$516(46 \cdot 6)$
1107
$676(60 \cdot 4)$
$443(39 \cdot 6)$
1119
$821(72 \cdot 8)$
$307(27 \cdot 2)$
1128

$1 \cdot 15$

$(0 \cdot 87-1 \cdot 51)$

$0 \cdot 30 \quad 149(84 \cdot 2)$

$28(15 \cdot 8)$

$1 \cdot 12$

$(0 \cdot 70-1 \cdot 80)$

$1 \cdot 07$

$(0 \cdot 88-1 \cdot 30)$

$0 \cdot 50$

177

$1 \cdot 07$

$(0 \cdot 75-1 \cdot 53)$

$63(35 \cdot 8)$

176

$1 \cdot 14(0 \cdot 95-1 \cdot 38) \quad 0 \cdot 27$

$107(60 \cdot 5)$

$62(35 \cdot 0)$

$0.86(0.57-1 \cdot 30)$

$8(4 \cdot 5)$

$-$

$1 \cdot 14(0.94-1 \cdot 37) \quad 0.42$

$0.78(0.55-1 \cdot 11)$

$0.97(0.74-1.26)$

$-$

177

$114(64 \cdot 4)$

$7(4 \cdot 0)$

$23(13 \cdot 0)$

$33(18 \cdot 6)$

177

$1 \cdot 01(0 \cdot 83-1 \cdot 22) \quad 0 \cdot 91$

$91(51 \cdot 7)$

$85(48 \cdot 3)$

176

$1 \cdot 08(0 \cdot 89-1 \cdot 31) \quad 0 \cdot 41$

$113(64 \cdot 6)$

$62(35 \cdot 4)$

175

$0 \cdot 84(0 \cdot 59-1 \cdot 18)$

$1 \cdot 14(0.80-1 \cdot 62)$

$1 \cdot 17(0 \cdot 52-2 \cdot 74)$

$-$

$0.86(0.60-1 \cdot 22)$

$0 \cdot 32$

$1.85(0.80-4.50)$

$1 \cdot 13(0.68-1 \cdot 87)$

$-$

$133(76)$
$42(24)$
175

$0 \cdot 26$

0.66

$0 \cdot 77$

$1.08(0.77-1.52)$

0.64

$1 \cdot 01(0 \cdot 82-1 \cdot 24) \quad 0.94$

C.I., confidence interval.

Table 3 Analysis of the five marker (SNPs only) and seven marker (including microsatellites) haplotypes. The five SNP haplotypes are made up of the alleles: rs3761549-rs2232365-rs2280883-rs2294021-rs6609857 respectively. The seven-marker haplotype also includes the two microsatellite markers (GT) $n$ and (TC)n. Only haplotypes with frequencies $>0.01$ in each group are listed

\begin{tabular}{|c|c|c|c|c|c|c|c|}
\hline & Controls & GD & $P$ value & OR (95\% C.I.) & AAD & $P$ value & OR (95\% C.I.) \\
\hline \multicolumn{8}{|c|}{ Five marker halotype } \\
\hline CGCCC & 0.50 & 0.45 & 0.07 & $0.83(0.68-1.02)$ & $0 \cdot 47$ & 0.64 & $0.92(0.64-1.32)$ \\
\hline TGTCC & $0 \cdot 14$ & 0.14 & 0.70 & $1.06(0.79-1.41)$ & $0 \cdot 16$ & 0.51 & $1 \cdot 18(0.72-1.96)$ \\
\hline CATTC & 0.09 & $0 \cdot 13$ & 0.01 & $1 \cdot 51(1 \cdot 09-2 \cdot 11)$ & $0 \cdot 11$ & $0 \cdot 47$ & $1.25(0.69-2 \cdot 27)$ \\
\hline Other & 0.02 & 0.01 & - & - & 0.01 & - & - \\
\hline TGTCC 34 & $0 \cdot 15$ & $0 \cdot 18$ & $0 \cdot 17$ & $1.26(0.84-1.89)$ & $0 \cdot 19$ & 0.25 & $1 \cdot 39(0.76-2 \cdot 53)$ \\
\hline CATTC 414 & 0.08 & $0 \cdot 10$ & 0.24 & $1 \cdot 30(0 \cdot 77-2 \cdot 20)$ & $0 \cdot 10$ & 0.56 & $1.21(0.54-2 \cdot 68)$ \\
\hline CATTT 414 & 0.03 & 0.03 & 0.92 & $1.05(0.41-2.59)$ & 0.07 & 0.08 & $0.43(0.14-1 \cdot 30)$ \\
\hline CGCCC 44 & 0.02 & 0.03 & 0.48 & $1 \cdot 31(0.50-3 \cdot 57)$ & 0.03 & 0.53 & $1.42(0 \cdot 33-5 \cdot 66)$ \\
\hline Other & $0 \cdot 13$ & $0 \cdot 18$ & - & - & 0.09 & - & - \\
\hline
\end{tabular}

OR, odds ratio. 
variation at or near FOXP3 is not associated with T1D. There have also been discrepant reports on the role of FOXP3 in non-endocrine autoimmune diseases (Park et al. 2005, Sanchez et al. 2005). A true association of an allele with a disease would not be expected to be positive in every study population, and this may be compounded by the different ethnic origins of the sample populations in the three studies of autoimmune endocrinopathies to date. The initial positive study (Bassuny et al. 2003) was carried out in a Japanese population whilst the two negative studies were both in white Caucasians (Sardinian (Zavattari et al. 2004) and United Kingdom (UK) populations (current study)). Recent reports have shown a significant difference in allele frequencies among different ethnicities (Yamazaki et al. 2004, Mori et al. 2005), particularly between Japanese and Caucasian populations (Yamazaki et al. 2004), and our results illustrate this. The allele frequencies of the markers in common between the studies is similar in the two European populations (UK and Sardinian), but markedly different within the Japanese population (25\% difference in allele frequency for marker (GT) $n$ allele 4). This ethnic variation in disease susceptibility alleles has been seen recently with other genes, e.g. PADI4 gene polymorphisms have been associated with rheumatoid arthritis in the Japanese population (Suzuki et al. 2003) but not within European populations (Barton et al. 2004, Caponi et al. 2005, Martinez et al. 2005).

A meta-analysis summary of common disease susceptibility polymorphisms in different populations found that for a replicated disease-associated allele, the relative risk tended to be similar in different ethnic groups despite different background allele frequencies (Ioannidis et al. 2004). It is clearly the case that, if a true susceptibility locus has been identified, then an association should be found in every population. However, if the candidate allele is only in linkage disequilibrium with the true susceptibility locus, the association may only exist in certain populations due to ancestral haplotype structure (Gambano et al. 2000). This may lead to the rejection of a true association in a specific population because the allele being typed is not the actual disease susceptibility locus. Inconsistencies between different ethnic groups may also reflect complex interactions between multiple population-specific genetic and environmental factors.

In summary, we have found no robust evidence for association of the FOXP3 gene with GD or AAD in our northeast of England population. However, we cannot rule out the possibility that a polymorphism carried on the minor haplotype (CATTC) that shows nominal evidence for association $(P=0 \cdot 01)$ might have a role. Nevertheless, we have gleaned genetic information encompassing more than $98 \%$ of all haplotype combinations across the $15 \cdot 7 \mathrm{~kb}$ FOXP 3 locus by genotyping these five SNPs and two microsatellites (Table 2). FOXP3 is a candidate gene for autoimmune diseases mainly due to its increasingly understood important role in immune regulation and the fact that mutations in the gene are responsible for the condition IPEX. However, more specific studies into the functional role of this gene in autoimmune disease will be necessary before it can be said to have a biologically defined role in autoimmunity. There is still no clear answer as to whether FOXP3 is relevant in more complex autoimmune endocrinopathies such as T1D, GD and AAD, and further studies on large cohorts of patients with these conditions in a variety of ethnic populations are still required to increase our knowledge-base for this gene.

\section{Acknowledgements}

We wish to thank all the patients and controls who have assisted with this study.

\section{Funding}

This work was supported by the Medical Research Council, UK through an MRC clinical research training fellowship for $\mathrm{C} \mathrm{J} \mathrm{O}$. None of the authors believes themselves to have any conflict of interest with the publication of this work.

\section{References}

Allen EM, Hsueh W, Sabra MM, Pollin TI, Ladenson PW, Silver KD, Mitchell BD \& Shuldiner AR 2003 A genome-wide scan for autoimmune thyroiditis in the Old Order Amish: replication of genetic linkage on chromosome $5 q 11 \cdot 2-q 14 \cdot 3$. Journal of Clinical Endocrinology and Metabolism 88 1292-1296.

Altshuler D, Brooks LD, Chakravarti A, Collins FS, Daly MJ \& Donnelly P 2005 International HapMap consortium a haplotype map of the human genome. Nature 437 1299-1320.

Barbesino G, Tomer Y, Concepcion ES, Davies TF \& Greenberg DA 1998 Linkage analysis of candidate genes in autoimmune thyroid disease, II. Selected gender-related genes and the X-chromosome. Journal of Clinical Endocrinology and Metabolism 83 3290-3295.

Barrett JC, Fry B, Maller J \& Daly MJ 2005 Haploview: analysis and visualization of LD and haplotype maps. Bioinformatics 21 263-265.

Barton A, Bowes J, Eyre S, Spreckley K, Hinks A, John S \& Worthington J 2004 A functional haplotype of the PADI4 gene associated with rheumatoid arthritis in a Japanese population is not associated in a United Kingdom population. Arthritis and Rheumatism 50 1117-1121.

Bassuny WM, Ihara K, Sasaki Y, Kuromaru R, Kohno H, Matsuura N \& Hara T 2003 A functional polymorphism in the promoter/ enhancer region of the FOXP3/Scurfin gene associated with type 1 diabetes. Immunogenetics 55 149-156.

Bennett CL, Brunkow M, Ramsdell F, O’Briant K, Zhu Q, Fuleihan R, Shigeoka A, Ochs H \& Chance P 2001 $a$ A rare polyadenylation signal mutation of the FOXP3 gene (AAUAAA->AAUGAA) leads to the IPEX syndrome. Immunogenetics 53 435-439. 
Bennett CL, Christie J, Ramsdell F, Brunkow ME, Ferguson PJ, Whitesell L, Kelly TE, Saulsbury FT, Chance PF \& Ochs HD $2001 b$ The immune dysregulation, polyendocrinopathy, enteropathy, $\mathrm{X}$-linked syndrome (IPEX) is caused by mutations of FOXP3. Nature Genetics 27 20-21.

Brunkow ME, Jeffery EW, Hjerrild KA, Paeper B, Clark LB, Yasayko S-A, Wilkinson JE, Galas D, Ziegler SF \& Ramsdell F 2001 Disruption of a new forkhead/winged-helix protein, scurfin, results in the fatal lymphoproliferative disorder of the scurfy mouse. Nature Genetics $\mathbf{2 7}$ 68-73.

Caponi L, Petit-Teixeira E, Sebbag M, Bongiorni F, Moscato S, Pratesi F, Pierlot C, Osorio J, Chapuy-Regaud S, Guerrin M et al. 2005 A family based study shows no association between rheumatoid arthritis and the PADI4 gene in a white French population. Annals of the Rheumatic Diseases 64 587-593.

Chatila TA, Blaeser F, Ho N, Lederman HM, Voulgaropoulos C, Helms C \& Bowcock AM 2000 JM2, encoding a fork head-related protein, is mutated in X-linked autoimmunity-allergic disregulation syndrome. Journal of Clinical Investigation 106 R75-R81.

Chitnis S, Monteiro J, Glass D, Apatoff B, Salmon J, Concannon P \& Gregersen PK 2000 The role of X-chromosome inactivation in female predisposition to autoimmunity. Arthritis Research $\mathbf{2}$ 399-406.

Cornelis F, Faure S, Martinez M, Prud'homme J-F, Fritz P, Dib C, Alves H, Barrera P, de Vries N, Balsa A et al. 1998 New susceptibility locus for rheumatoid arthritis suggested by a genome-wide linkage study. PNAS 95 10746-10750.

Cucca F, Goy JV, Kawaguchi Y, Esposito L, Merriman ME, Wilson AJ, Cordell HJ, Bain SC \& Todd JA 1998 A male-female bias in type 1 diabetes and linkage to chromosome Xp in MHC HLA-DR3-positive patients. Nature Genetics 19 301-302.

Dudbridge F 2003 Pedigree disequilibrium tests for multilocus haplotypes. Genetic Epidemiology 25 115-121.

Ebers GC, Kukay K, Bulman DE, Sadovnick AD, Rice G, Anderson C, Armstrong H, Cousin K, Bell RB, Hader W et al. 1996 A full genome search in multiple sclerosis. Nature Genetics 13 472-476.

Fontenot JD, Gavin MA \& Rudensky AY 2003 Foxp3 programs the development and function of $\mathrm{CD} 4+\mathrm{CD} 25+$ regulatory $\mathrm{T}$ cells Nature Immunology 4 330-336.

Gambano G, Anglani F \& D'Angelo A 2000 Association studies of genetic polymorphisms and complex disease. Lancet 355 308-311.

Gambineri E, Torgerson TR \& Ochs HD 2003 Immune dysregulation, polyendocrinopathy, enteropathy, and X-linked inheritance (IPEX), a syndrome of systemic autoimmunity caused by mutations of FOXP3, a critical regulator of T-cell homeostasis. Current Opinion in Rheumatology 15 430-435.

Hori S, Nomura T \& Sakaguchi S 2003 Control of regulatory T cell development by the transcription factor Foxp3. Science $\mathbf{2 9 9}$ 1057-1061.

Huan J, Culbertson N, Spencer L, Bartholomew R, Burrows G, Chou Y, Bourdette D, Ziegler S, Offner H \& Vandenbark A 2005 Decreased FOXP3 levels in multiple sclerosis patients. Journal of Neuroscience Research 81 45-52.

Imrie H, Vaidya B, Perros P, Kelly WF, Toft AD, Young ET, KendallTaylor P \& Pearce SHS 2001 Evidence for a Graves' disease susceptibility locus at chromosome Xp11 in a United Kingdom population. Journal of Clinical Endocrinology and Metabolism 86 $626-630$.

Ioannidis JPA, Ntzani EE \& Trikalinos TA 2004 'Racial' differences in genetic effects for complex diseases. Nature Genetics 36 1312-1318.

Jin Y, Teng W, Ben S, Xiong X, Zhang J, Xu S, Shugart YY, Jin L, Chen J \& Huang W 2003 Genome-wide scan of Graves' disease: evidence for linkage on chromosome 5q31 in Chinese Han pedigrees. Journal of Clinical Endocrinology and Metabolism 88 1798-1803.

Khattri R, Cox T, Yasayko S-A \& Ramsdell F 2003 An essential role for Scurfin in CD4+CD25 + T regulatory cells. Nature Immunology 4 337-342.
Kobayashi I, Shiari R, Yamada M, Kawamura N, Okano M, Yara A, Iguchi A, Ishikawa N, Ariga T, Sakiyama Y et al. 2001 Novel mutations of FOXP3 in two Japanese patients with immune dysregulation, polyendocrinopathy, enteropathy, X linked syndrome (IPEX). Journal of Medical Genetics 38 874-876.

Kriegel MA, Lohmann T, Gabler C, Blank N, Kalden JR \& Lorenz H-M 2004 Defective suppressor function of human CD4+ CD25 + regulatory $\mathrm{T}$ cells in autoimmune polyglandular syndrome type II. Journal of Experimental Medicine 199 1285-1291.

Kukreja A, Cost G, Marker J, Zhang C, Sun Z, Lin-Su K, Ten S, Sanz M, Exley M, Wilson B et al. 2002 Multiple immuno-regulatory defects in type-1 diabetes. Journal of Clinical Investigation 109 131-140.

Laureti S, Vecchi L, Santeusanio F \& Falorni A 1999 Is the prevalence of addison's disease underestimated? Journal of Clinical Endocrinology and Metabolism 841762.

Lockshin MD 2002 Sex ratio and rheumatic disease. Autoimmunity Reviews 1 162-167.

Maloy KJ \& Powrie F 2001 Regulatory T cells in the control of immune pathology. Nature Immunology 2 816-822.

Martinez A, Valdivia A, Pascual-Salcedo D, Lamas JR, FernandezArquero M, Balsa A, Fernandez-Gutierrez B, de la Concha EG \& Urcelay E 2005 PADI4 polymorphisms are not associated with rheumatoid arthritis in the Spanish population. Rheumatology 44 1263-1266.

Mori M, Yamada R, Kobayashi K, Kawaida R \& Yamamoto K 2005 Ethnic differences in allele frequency of autoimmune-diseaseassociated SNPs. Journal of Human Genetics 50 264-266.

Owen CJ, Jennings CE, Imrie H, Lachaux A, Bridges NA, Cheetham TD \& Pearce SHS 2003 Mutational analysis of the FOXP3 gene and evidence for genetic heterogeneity in the immunodysregulation, polyendocrinopathy, enteropathy syndrome. Journal of Clinical Endocrinology and Metabolism 88 6034-6039.

Ozbalkan Z, Bagislar S, Kiraz S, Akyerli CB, Ozer HT, Yavuz S, Birlik AM, Calguneri M \& Ozcelik T 2005 Skewed X chromosome inactivation in blood cells of women with scleroderma. Arthritis and Rheumatism $\mathbf{5 2}$ $1564-1570$.

Ozcelik T, Uz E, Akyerli CB, Bagislar S, Mustafa CA, Gursoy A, Akarsu N, Toruner G, Kamel N \& Gullu S 2006 Evidence from autoimmune thyroiditis of skewed X-chromosome inactivation in female predisposition to autoimmunity. European Journal of Human Genetics 14 791-797.

Park O, Grishina I, Leung P, Gershwin M \& Prindiville T 2005 Analysis of the Foxp3/Scurfin gene in Crohn's disease. Annals of the New York Academy of Sciences 1051 218-228.

Sakaguchi S, Sakaguchi N, Shimizu J, Yamazaki S, Sakihama T, Itoh M, Kuniyasu Y, Nomura T, Toda M \& Takahashi T 2001 Immunologic tolerance maintained by CD25 + CD4 + regulatory T cells: their common role in controlling autoimmunity, tumor immunity, and transplantation tolerance. Immunological Reviews 182 18-32.

Sakai K, Shirasawa S, Ishikawa N, Ito K, Tamai H, Kuma K, Akamizu T, Tanimura M, Furugaki K, Yamamoto K \& Sasazuki T 2001 Identification of susceptibility loci for autoimmune thyroid disease to 5q31-q33 and Hashimoto's thyroiditis to 8q23-q24 by multipoint affected sib-pair linkage analysis in Japanese. Human Molecular Genetics 10 1379-1386.

Sanchez E, Rueda B, Orozco G, Oliver J, Vilchez JR, Paco L, LopezNevot MA, Callejas JL, Sabio JM \& Gomez-Garcia M 2005 Analysis of a GT microsatellite in the promoter of the foxp3/scurfin gene in autoimmune diseases. Human Immunology 66 869-873.

Stewart JJ 1998 The female X-inactivation mosaic in systemic lupus erythematosus. Immunology Today 19 352-357.

Suzuki A, Yamada R, Chang X, Tokuhiro S, Sawada T, Suzuki M, Nagasaki M, Nakayama-Hamada M, Kawaida R, Ono M et al. 2003 Functional haplotypes of PADI4, encoding citrullinating enzyme peptidylarginine deiminase 4 , are associated with rheumatoid arthritis. Nature Genetics 34 395-402. 
Taylor J, Gough S, Hunt P, Brix T, Chatterjee K, Connell J, Franklyn J, Hegedus L, Robinson B, Wiersinga W et al. 2006 A genome-wide screen in 1119 relative pairs with autoimmune thyroid disease. Journal of Clinical Endocrinology and Metabolism 91 646-653.

TomerY, Barbesino G, Greenberg DA, Concepcion E \& Davies TF 1999 Mapping the major susceptibility loci for familial Graves' and Hashimoto's diseases: evidence for genetic heterogeneity and gene interactions. Journal of Clinical Endocrinology and Metabolism 84 $4656-4664$.

TomerY, Ban Y, Concepcion E, Barbesino G, Villanueva R, Greenberg DA \& Davies TF 2003 Common and unique susceptibility loci in Graves and Hashimoto diseases: results of whole-genome screening in a data set of 102 multiplex families. American Journal of Human Genetics 73 736-747.

Tunbridge W, Evered DC, Hall R, Appleton D, Brewis M, Clark F, Evans JG, Young E, Bird T \& Smith PA 1977 The spectrum of thyroid disease in a community: the Whickham survey. Clinical Endocrinology (Oxford) 7 481-493.

Walker LSK, Chodos A, Eggena M, Dooms H \& Abbas AK $2003 a$ Antigen-dependent proliferation of CD4 + CD25 + regulatory T cells in vivo. Journal of Experimental Medicine 198 249-258.

Walker R, Kasprowicz DJ, Gersuk VH, Benard A, Van Landeghen M, Buckner JH \& Ziegler SF $2003 b$ Induction of FoxP3 and acquisition of T regulatory activity by stimulated human CD $4+$ CD25 - T cells. Journal of Clinical Investigation 112 1437-1443.

Werner SC 1977 Modification of the classification of the eye changes of Graves' disease: recommendations of the ad hoc committee of the
American Thyroid Association. Journal of Clinical Endocrinology and Metabolism 44 203-204.

Wildin RS, Ramsdell F, Peake J, Faravelli F, Casanova J-L, Buist N, LevyLahad E, Mazzella M, Goulet O, Perroni L et al. 2001 X-linked neonatal diabetes mellitus, enteropathy and endocrinopathy syndrome is the human equivalent of mouse scurfy. Nature Genetics 27 18-20.

Wildin RS, Smyk-Pearson S \& Filipovich AH 2002 Clinical and molecular features of the immunodysregulation, polyendocrinopathy, enteropathy, X linked (IPEX) syndrome. Journal of Medical Genetics 39 537-545.

Woolf B 1995 On estimating the relation between blood group and disease. Annals of Human Genetics 19 251-253.

Yamazaki K, Takazoe M, Tanaka T, Ichimori T, Saito S, Iida A, Onouchi Y, Hata A \& Nakamura Y 2004 Association analysis of SLC22A4, SLC22A5 and DLG5 in Japanese patients with Crohn disease. Journal of Human Genetics 49 664-668.

Zavattari P, Deidda E, Pitzalis M, Zoa B, Moi L, Lampis R, Contu D, Motzo C, Frongia P, Angius E et al. 2004 No association between variation of the FOXP3 gene and common type 1 diabetes in the Sardinian population. Diabetes 53 1911-1914.

Received in final form 13 April 2006

Accepted 2 May 2006 